\title{
Editorial
}

\section{Art, science and technology, brief reflections on interdisciplinary work}

\section{Wilson J. Sarmiento ${ }^{1}$ and Santiago Mesa Romero ${ }^{2}$}

${ }^{1}$ Grupo de Investigación en Multimedia, Programa de Ingeniería en Multimedia, Facultad de Ingeniería, Universidad Militar Nueva Granada, Bogotá D. C., Colombia

${ }^{2}$ Maestría en Artes Digitales, Facultad de Artes y Humanidades, Instituto Tecnológico Metropolitano, Medellín-Colombia

Interdisciplinary work is necessary to respond to the challenges of the current society. For instance, the partnership between technology, humanities and arts, had allowed the contemporary development of interactive systems. An example is the fact that producing a smartphone involves graphic designers, psychologists, illustrators, sociologists, and other professionals, including engineers. One might say the same about the development of video games, laptops, movies and computer mice. In summary, behind of the creation of any "technological artifact" there is hard interdisciplinary work.

The partnership technology-humanities-arts is a result of a continuous evolution of both the industrial and the academic sector. Probably, the earliest evidence of this partnership is the Chinese shadows puppetry and similar theater expressions in Europe that may be considered the forefathers of multimedia and the first interactive systems [1]. In those exhibits, the principle of the alliance between art and technology was evident: the search for better ways of artistic expression encourages the development of new technologies. Today, video mapping shows [2], algoraves/live coding concerts [3], net.art works [4] and interactive artworks [5], among other expressions, are consequences of the same principle: a need to express (cause) followed by the implementation or development of a technology (effect). The association between technology, humanities and arts can be interpreted as a permanent dialogue by different forms of knowledge —namely "Science, philosophy and Art" [6] - to face the new challenges and complexities of society nowadays. Art, science and new technologies open a new field of experimentation and creation of ways to interact with reality.

In some cases, the effect derived from a necessity is more complicated, it is a deliberation or a study field. Human-computer interaction (HCI) is a response to specific requirements, to the search for more natural, easier-to-use, user-friendly interactive systems [7]. As a result, at the heart of the questions and goals of any HCI subfield e.g. computer-supported cooperative work [8], affective computing [9] and multicultural interfaces [10] - lies the improvement of user-system-user communication.

Interactive systems are a loop. They are a response to the needs of a user, a solution to a technical obstacle, the idea that needs expression. However, they also pose a usability problem; these artifacts need to be improved. They represent answers and questions in the user-centered interaction loop. Furthermore, the fact that these answers and questions are immersed in the relationship between technology, humanities should not be forgotten [5]. 
From the perspective of art, the new forms of production and distribution of artistic experiences, the conception of the work of art and the relationship between artists and the public make technology a means of creation and a field of reflection itself. Cause and effect have a two-way relationship. These experiences allow to raise new questions about the cultural transformations of the world at present: the role of technology in human interactions, the development of new forms of expression and new materials for creating.

For that reason, interdisciplinary work is the priority inside interaction labs (both of industrial and academic sectors), which are spaces that adopted interaction loop as inspiration philosophy. . The Institute for Creative Technologies of the University of Southern California ${ }^{1}$, the Center for Science and the Imagination of Arizona State University $^{2}$, the MediaLab of Massachusetts Institute of Technology ${ }^{3}$, and the MediaLab Prado $^{4}$ of the Department of Culture and Sports of the City of Madrid are recognized examples of this type of labs in academic spaces. Such facilities are well equipped to support the creation of artistic works with technology and new solutions to interaction problems.

In our country, the number of proposals in this field is growing. One of them is the popular International Image $\mathrm{Festival}^{5}$, which enjoys high academic prestige and gathers experts in arts and visual communication. In recent years, it has been focused on media art and similar art expressions supported by technology.

Currently, several university programs address the future and present challenges and complexities of this field of knowledge, which requires multidisciplinary, transdisciplinary and interdisciplinary work. In fact, our institutions have proposals in similar regards. The Universidad Militar Nueva Granada is the first university in the country to offer a Multimedia Engineering 6 undergraduate program that trains students with aesthetic sensibility and capabilities in engineering to generate solutions to problems related to the creation, analysis, processing and presentation of multimedia content. Another proposal is the Multimedia Conference ${ }^{7}$, an event that seeks to bring together experts in analysis, processing and production of multimedia information. The Metropolitan Institute of Technology in Medellín has recently introduced a new program: Master's in Digital Arts $^{8}$, which offers graduate training to professionals in various disciplines. This program is a project of the Faculty of Arts and Humanities in partnership with the Faculty of Engineering of the institution is characterized by the permanent relationship between different forms of knowledge: art, science and philosophy.

For this thematic issue, researchers in Arts/Technology and Interactive Systems were invited to submit original works as a collaborative proposal between our two institutions. We received 18 papers, four of which are published in this issue in the thematic section. Four other articles continue in the editorial process; they will be

\footnotetext{
$1 \mathrm{http}: / /$ ict.usc.edu/

2 http://csi.asu.edu/

$3 \mathrm{https} / / /$ www.media.mit.edu/

4 http://medialab-prado.es/

$5 \mathrm{http}: / /$ festivaldelaimagen.com

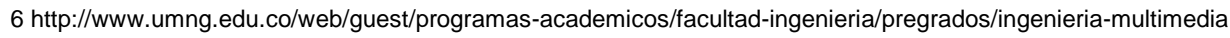

7 http://congresomultimedia.umng.edu.co/

$8 \mathrm{http}: / /$ www.itm.edu.co/facultades/facultad-de-artes-y-humanidades-18/formacion-2/maestria-en-artes-digitales-2/
}

[10] TecnoLógicas, ISSN-p 0123-7799 / ISSN-e 2256-5337, Vol. 21, No. 41, enero-abril de 2018, pp. 9-11 
included in the regular section in future issues. We look forward to accepting other collaborative proposals by the Arts/Technology and Interactive Systems community. Last but not least, we would like to express our gratitude to the team of reviewers who accepted the assignments within such tight schedule.

\section{REFERENCES}

[1] O. Özcan, "Cultures, the Traditional Shadow Play, and Interactive Media Design,” Des. Issues, vol. 18, no. 3, pp. 18-26, Jul. 2002.

[2] H. Yoo and H. Kim, "On Study of the Projection Mapping In Media Arts," Adv. Sci. Technol. Lett., vol. 54, pp. 73-76.

[3] N. Collins, "Live Coding of Consequence," Leonardo, vol. 44, no. 3, pp. 207-211, Jun. 2011.

[4] J. Stallabrass, "The aesthetics of NET.ART," Qui Parle, vol. 14, no. 1, pp. 49-72, 2003.

[5] L. J. Ball, D. Ramduny-Ellis, D. Rachovides, and British HCI Group., "Encouraging witting participation and performance in digital live art," in Proceedings of the 21st British HCI Group Annual Conference on People and Computers: HCI...but not as we know it - Volume 1, 2007, pp. 13-23.

[6] G. Deleuze and F. Guattari, ¿Qué es la filosofía? Anagrama, Colección Argumentos, 2006.

[7] A. Dix, "Human-computer interaction: A stable discipline, a nascent science, and the growth of the long tail," Interact. Comput., vol. 22, no. 1, pp. 13-27, Jan. 2010.

[8] J. Grudin, "Computer-supported cooperative work: history and focus," Computer (Long. Beach. Calif)., vol. 27, no. 5, pp. 19-26, 1994.

[9] E. Cambria, "Affective Computing and Sentiment Analysis," IEEE Intell. Syst., vol. 31, no. 2, pp. 102-107, 2016.

[10] M. G. McKenna and H. Naftulin, "Challenges in the multicultural HCI development environment," in CHI '00 extended abstracts on Human factors in computing systems - CHI'00, 2000, p. 362. 